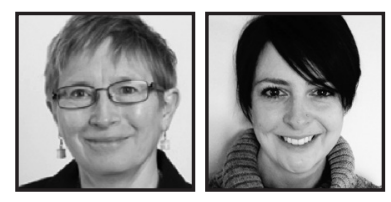

\title{
"'Cause It Has to Happen": Exploring Teachers' Resistance to LGBT Literature and Issues in a Teacher Inquiry Group
}

\author{
Lynne Wiltse and Theresa Boyko, University of Alberta
}

\section{ABSTRACT}

This paper explores teachers' resistance to LGBT literature and issues by examining how a group of teachers, as part of a social justice research project, responded to an article that examined reasons why teachers who hold anti-homophobic views still resist teaching LGBT texts and topics in their classrooms. Boler and Zembylas's (2002) notion of a "pedagogy of discomfort" provides a framework for understanding reluctance to move out of one's comfort zone. The story of how one of the research participants pushed the boundaries of possibility by undertaking subsequent professional development initiatives at her school offers an alternative to teacher resistance.

\section{Lynne's Story}

n the winter of 2013, an article in the journal Language Arts caught my attention: Teachers' Resistance to LGBT Literature and Issues (Haertling Thein, 2013).' Four decades ago, when I took a children's literature course during my education degree, I could not have imagined that LGBT literature would be available for teachers to use with their students, or that there would be articles about this topic in professional education journals. That I would one day challenge my own undergraduate students' discussion of stereotypes in the picture book, Mom and Mum get Married (Setterington, 2004), with a personal anecdote from my own same-sex wedding would have seemed a fairy tale. Although times have changed, I am not surprised by the suggestion that teachers remain resistant to LGBT literature and issues. I am troubled, though. The title of 
Smolkin and Young's (2011) article, Missing Mirrors, Missing Windows: Children's Literature Textbooks and LGBT Topics, captures my concern. The authors make the point that:

all children deserve to have access to books in schools that are reflective of their cultures. Such books are seen as self-affirming mirrors for children of a given culture and as windows into other lives for children outside that given culture. Both are important factors in developing empathy and understanding in cross-cultural interactions. (p. 217)

In their article, Smolkin and Young acknowledge the progress we have made since "Larrick's (1965) all white world of children's books" (p. 217), at the same time pointing out that LGBT children or children of LGBT families seldom have their lives "mirrored in the books they find in schools" (p. 217). I can appreciate the authors' comments. When I began my teaching career in small Aboriginal communities more than 30 years ago, it was difficult for Aboriginal students to see themselves represented in the books they read at school; students from various ethnocultural backgrounds faced a similar situation (Wiltse, 2015). Fortunately, there has been an upsurge in texts authored by immigrant and first generation Canadians, as well as increased publication of children's literature by authors of Aboriginal heritage. Teachers are now better able to consider cultural diversity in relation to text selection, so that students can recognize themselves in the texts they are offered at school. Although limited in comparison, there is also a growing collection of books for children and youth that deal with LGBT topics. As the titles of both Haertling Thein's and Smolkin and Young's articles suggest, these books are rarely making their way into classrooms.

Although both papers speak to the American situation, parallels can be made to the Canadian context. Over the last several years, I have introduced a wide selection of diverse literature to pre-service and in-service teachers in my language and literacy and children's literature courses as well as in research projects. My students and research participants have used many of these books (and others) in their teaching to address various social justice issues, ranging from residential schooling and contemporary Aboriginal issues to historical and current topics of war. In contrast, the uptake on the LGBT books has been minimal, with one notable exception. The exception was Erica, ${ }^{2}$ one of my students in a small teacher education program in the interior of British Columbia, and a research participant in a national study that placed Canadian multicultural picture books in the hands of pre-service teachers. ${ }^{3}$

During her field experience in a primary classroom, Erica was asked to teach a unit about families. In an attempt to be inclusive, she selected a wide array of books 
about different kinds of families, and chose Asha's Mums (Elwin \& Paulse, 1990), one of the picture books in the research study collection, to represent children who may have same-sex parents. Asha's Mums tells the story of a young girl who must explain to her teacher and classmates that having two mums is not a problem because they are a family. When Erica provided her teacher mentor with an overview of the unit, she requested that Erica talk to the principal about her choice. In the following interview excerpt, Erica describes their conversation:

He had a problem with Asha's mums. He went on the internet and pulled up the information based on what happened down in Surrey. He said this book was too controversial and asked me what was I trying to do in the classroom with this book. I told him I'm celebrating all kinds of different families as there's a lot of variations of families now, including quite a few in that classroom. He said that he didn't want a parent coming in and getting all upset about this sort of thing, and that if there's a problem with having same sex parents at his school, he'd deal with it. I just thought, "Well, why wouldn't you be proactive?"

Why not indeed? "What happened in Surrey" is that when James Chamberlain, a primary school teacher, requested permission from the Surrey School District to use Asha's Mums and two other books that featured families with same-sex parents to reflect contemporary families, the board voted against the request. A legal battle that went all the way to the Supreme Court of Canada ensued; the court decreed that the school board could not impose its religious values by refusing to permit the use of books to promote tolerance of same-sex relationships (Chamberlain v. Surrey School District No. 36). ${ }^{4}$ As Erica had learned about the court case in our children's literature course, she knew the Supreme Court's decision prevented school boards from banning books based on their own views and that the ruling noted that families headed by same-sex parents need to be respected. But, as a pre-service teacher in a small school district in which she hoped to apply for a teaching position, Erica felt powerless, and removed the book from her unit.

Haertling Thein's study (2013) rekindled my interest in this topic. The author found that even language arts teachers who held anti-homophobic views may "still resist teaching LGBT texts and issues in their classrooms" (p. 169). Anti-homophobic is how I would describe the teachers in my research study, Engaging Teachers With Canadian Literature for Social Justice. Project funds provided participating teachers with the opportunity to select a class set of contemporary Canadian-authored texts for their students to read. In monthly inquiry groups, the teachers examined the academic literature in the field, in addition to discussing pedagogical strategies for teaching their 
selected books. In the hope that the Haertling Thein article would spark discussion, I asked the teachers to read the paper for our next meeting. The reading did generate thought-provoking conversation, and in the case of one of the research participants, Theresa, provided the impetus for further action. At the time, Theresa was curriculum coordinator at a local school, and a graduate student working on her Master's degree with a particular interest in the idea of transformative leadership and leading for social justice. The article facilitated Theresa's realization that LGBT literature and issues were areas for attention at her school; she became involved in professional development initiatives that pushed the boundaries of possibility. What ensued led to this article.

We will begin with a brief explanation of study details for the research project in which we were involved, followed by a summary of Haertling Thein's article that served as the catalyst for this paper. Next, select comments from the inquiry group conversation will be provided. Theresa will then offer an account of the professional development that she undertook at her school. In the follow-up discussion, we offer suggestions for decreasing teacher resistance to LGBT literature and issues.

\section{Study Details for the Teacher Inquiry Group}

Our inquiry group was part of a three-year national research study designed to explore possibilities for teaching contemporary Canadian literature for children and youth to promote issues of social justice in Grades 4 to 12 classrooms (our inquiry group was for Grades 4-6). The primary purpose of the teacher inquiry groups was for teachers to select and teach one or more texts, and to discuss pedagogical strategies for teaching these texts in ways that engage students to reflect on structural and social inequities in Canadian society.

In designing the theoretical framework of the study, we drew on contemporary theories of social justice that see teachers as agents of social change attending to issues of race, class, gender, and language (Cochran-Smith, 2004; McDonald, 2007) and studies that emphasize the role of literature in advocacy research in literacy education (Bender-Slack, 2010; Cherland \& Harper; 2007; Wolk, 2009). In conceptualizing our inquiry group approach, the work of Wenger (1998) and Cochran-Smith and Lytle (2009), who promote possibilities for individuals in communities to engage in inquiry around their own practice in an attempt to improve curriculum, pedagogy, and student outcomes, was utilized. As the study progressed, we also began to examine the ways in which study findings resonated with Boler and Zembylas's (2003) notion of a 
"pedagogy of discomfort" that questions contemporary certainties shaped by dominant norms and highlights gaps and absences in current curricular practices.

Our inquiry group with 10 teachers was one of six sites in the national study, each constituting a descriptive case study. Together with our teacher participants, we followed an action research model of understanding a research problem, planning, acting, observing, reflecting, and reviewing (Carr \& Kemmis, 1986), as participants worked through the curricular and pedagogical possibilities of teaching for social justice with Canadian literature. Data were collected from audio-recorded discussions in the teachers' inquiry group, classroom observations of teaching, and subsequent curricular reflections in the inquiry group. At the time of the article discussion, we were in the second year of the study.

\section{Summary of Haertling Thein's Article}

Haertling Thein's study was designed to illuminate some of the reasons why language arts teachers may hold anti-homophobic views but still resist teaching LGBT texts and issues in their classrooms. The data were collected from the participants, 20 language arts teachers enrolled in an online master's course on multicultural literature instruction at an American university (one week of the course focused on teaching LGBT issues and texts). In her paper, Haertling Thein challenges teachers to rethink their stances towards teaching LGBT texts and issues. To do so, she drew on Clark's (2010) research, which distinguishes between anti-work, a stance limited to disrupting heterosexist discourses and homophobic language, and ally-work, a stance which necessitates critical conversation regarding heteronormativity and homophobia. While anti-work is carried out at the individual level, ally-work targets systemic or institutional change. Haertling Thein compares the seeming neutrality of an antistance to a "colour-blind" stance towards racism (see Bonilla-Silva \& Forman, 2000). This framework helped her to make sense of the discrepancies between teachers' beliefs towards LGBT literature and issues and their unwillingness to take on ally-work.

Haertling Thein's (2013) analysis identified six prominent categories regarding participants' unwillingness to teach LGBT texts: appropriateness; displaced negative stance; force of facts; reversal; fairness; and ability/preparedness (pp. 172-176). A brief description of each of the categories follows. The first category, termed appropriateness ( $/$ would, but it's not my job), was the most common way participants justified their unwillingness to teach LGBT issues and texts. Some participants equated 
this topic with sex which they believed did not belong in school or in the language arts classroom. Several participants argued that LGBT issues are important in schools, but the job lies with those in positions of greater power, not teachers. The second category, displaced negative stance (/ would, but others will protest), proved to be another a common justification. For example, many teachers argued that their conservative communities or rigid parent population would not approve while others said they would be unable to teach LGBT texts as students would respond with homophobia/ immaturity. Each of these qualifications was based on assumptions about the beliefs/ attitudes of others. Teachers who fell within the next reason, force of facts (I would, but the fact is...), claimed teaching LGBT texts/issues was not possible as it posed a direct threat to one's career, was explicitly prohibited, or even constituted the teaching of illegal activities. Haertling Thein labeled the next category, reversal (I would, but it will cause more harm than good). Reversals were used to suggest that teaching LGBT issues and texts would cause more harm than good. For example, teaching or discussing such issues would evoke bullying by straight students and embarrassment of LGBT students. Participants acknowledged value in teaching LGBT issues/texts and would do so "in an ideal world." Similar to justifications based on reversals were those grounded in fairness (I would, but it's not fair to everyone). This defense claimed teaching LGBT issues and texts would be unfair as the topic discriminates against students and parents who hold anti-gay views; participants used their belief in equality and the rights of antigay students as justification for avoidance. The last category of resistance was ability/ preparedness ("I would but I don't know how"). Some teachers pointed to their own deficits in attempting to teach LGBT texts and issues. Rather than being opposed, they felt ill-prepared or that they lacked an inherent ability for this kind of teaching.

\section{"Cause it Has to Happen": Participants' Responses to Reading}

On the whole, the research participants in our study were rather critical of the excuses made by the teachers in Haertling Thein's article. Theresa began the conversation with a critique of a comment within the category, I would, but it's not my job:

There were a lot of things in this article that really got my blood going actually, but one spot in particular on page 172, when Callie, an elementary school teacher said, "I have no problem with homosexuality, I'm not homophobic, etc. I have friends, I support their gay rights and feel they should not be denied anything that straight couples receive. Yet I am wishy washy on whether or not I feel that schools should 
show any support of any side of the issue." But we do that, by all of the choices that we make. The stories we use, the language we use often.

Theresa felt strongly as to the inappropriateness of the appropriateness justification: "I don't think that 'not my job' would be an argument, because I think we take care of kids emotionally and academically." Another participant's reasoning was similar:

I highlighted something by It's not part of their job. When I read this line, it caused me to question whether teaching is your job at all...That is an immediate flag for me. This statement defines a teacher's inability to think outside the box. Teaching in all its greyness is your job.

There was agreement on the part of the inquiry group that Callie's reasoning was not considered to be a valid reason for avoidance.

This led to a related point regarding the difference between the personal and the professional. Comments made by our participants suggested that they struggled to accept the lack of consistency shown by the teachers in the Haertling Klein article. For example, one teacher maintained:

If you get down to the root of it, teachers who aren't comfortable teaching this topic, are not comfortable with this personally. I think any teacher who is truly comfortable with LGBTQ has no problem bringing it into the classroom.

Another teacher expressed a similar view, but in a converse way: "I think if you're resisting the issue, there's something on a personal level that's resisting it." Despite their assessment, there was acknowledgement that there may be certain factors to consider. One teacher noted: "It could be these other issues that the teachers brought up-fear of that parent coming in after school and tearing your head off." Another participant added this for consideration: "And say you're a fresh grad, in your first 5 years of teaching and the fear that goes with that."

The significance of contextual factors corresponded to the displaced negative stance category. There was a general consensus amongst our research participants that I would but others will protest would be a common excuse. Theresa suggested that "I think others protesting would be a big one, and then I think that relates to it'll cause more harm than good, kind of keeping everybody happy and don't rock the boat." Concern about rocking the boat was a theme with which some of the participants could 
identify. For example, Thomas made the following comment about his current school, which was part of the public school district:

I would say it (LGBT issues) would be accepted. Looking back, though, when I started working for the Catholic district, it just wasn't something I would even consider. So, then, making the jump to the public district, I feel like I was more open to using LGBT topics. I think what held me back before was not being permanent and not wanting to rock the boat. But, now that I'm permanent, it's a different story.

As can be seen by Thomas's remark, there was the acknowledgment that circumstances such as the type of school/district in which teachers worked, as well as whether they had the security of a permanent contract played a role when it came to willingness to rock the boat-or not.

However, when it came to the reasons given by the teachers in Haertling Thein's study for the fairness argument (i.e., teaching LGBT issues and texts would discriminate against students and parents who hold anti-gay views), the participants in our study offered no such leeway. In this regard, they found Haertling Thein's comparison of colour-blind racism to an anti-stance towards homophobia instructive, as can be seen by the following:

At the end of that quote under fairness, it says that students need to know that their feelings and opinions are respected. Yeah, exactly why you need to approach it. And, comparing it to things like racism helps.

Being against LGBT issues is not a right. It's not that so and so's parents are racist, so we won't do a book about Black people because we need to respect their opinion. I find if you turn everything into a racist context, it makes you realize how silly it is... I don't think that some opinions should be respected. LGBTQ rights are human rights and we teach and respect human rights.

Well and that's just the thing. It's not an opinion-it's a human right.

The bottom line for the teachers in our study was that LGBT issues were a matter of human rights. Bonilla-Silva and Forman (2000) argue that we must "blow the whistle on color-blind racism" as it allows color-blind racists to "defend systemic White privilege" (p. 78). Similarly, we need to unmask views that support heterosexist and homophobic discourses. 
The participants touched on the final justification provided in Haertling Thein's article, that of ability/preparedness. For example, Theresa's opinion was that, "I think another reason would be I would, but I don't know how. I think that's valid. I'm not saying it should be an excuse or a reason, but I can see teachers using it." Another teacher expressed her viewpoint: "I think some people just use that as a cop out. That's their safe way of avoiding, even though they're probably a competent teacher. You can learn about the topic and teach it effectively." Although there was some disagreement as to the validity of this reason, all the participants agreed with the observation that what matters is "if you're open to learning it." For teachers who are open to learning, Theresa speaks to what is needed:

I think what the author wrote on the very first page about the NCTE (National Council of Teachers of English) passing the resolution advocating for strengthening teacher knowledge of LGBT issues... is huge. It is partly awareness and partly knowing that you'll be supported by the office if you choose to read the book and address these issues, 'cause it has to happen.

"'Cause it has to happen." I could not help but notice the passion of Theresa's assertion. While this inquiry group discussion proved to be one of our more animated, Theresa's voice seemed to rise above the others in its fervour. I hoped that the article and follow-up dialogue would prompt some of the teachers to choose an LGBT text to read to their students. However, I had not anticipated the ways in which Haertling Thein's article would provoke Theresa to push the boundaries of possibility regarding professional development. In the next section, Theresa will explain her story, how she went from her belief that it has to happen to making it happen.

\section{Making It Happen: Theresa's Story}

The intensity of my emotional response to Haertling Thein's article shocked me a bit. I found myself not only calling into question the excuses offered by the teachers in the article, but also, and perhaps more importantly, I immediately began reflecting on practices within our school context through which we may have been unwittingly marginalizing students who may be already marginalized.

Around the time we discussed this article, I was working towards attaining my Master's degree in Educational Studies and was called upon to create a growth plan reflecting a style of leadership that addressed district-level principal quality standards 
as well as personal and professional values. I decided on transformative leadership; leadership that challenges the status quo to ensure all students have equal access to school success (Shields, 2004). Examining current status quo for inequities is an important aspect of transformative leadership-leaders who empower staff and students to think critically about the "way things have always been done" are helping challenge Shields' notion of "pathologizing the lived experiences of students" (p. 112) or the practice of referring to student differences as deficits. The teachers' responses in Haertling Thein's article elicited a powerful emotional reaction; the notion of explaining away LGBT issues in the classroom contrasted sharply with my commitment to transformative leadership, rooted in action, underpinned by empowerment.

Through the research group I learned that I was also experiencing and encouraging others (colleagues and students) to experience a "pedagogy of discomfort"; the opportunity to move outside our comfort zones and "draw attention to the ways in which we enact and embody dominant values and assumptions in our daily routines" (Boler \& Zembylas, 2003, p. 111). When my commitment to transformative leadership intersected with my involvement with the research group, I moved from knowing something had to happen to taking action.

We began by exploring our choice of language. Seemingly innocuous words like "guys" were recognized as gender-exclusive and were quickly replaced with more intentional and inclusive language. We looked closely at the clubs we offered for our students and came to realize that although our intentions were honourable, we may have been doing more harm than good. In 2012 we created a boys' club and a girls' club to address peer-interaction issues that arose during unstructured recess times. Our goal was to teach our students pro-social skills and enhance their social-emotional competencies. An unfortunate by-product was that our heteronormative paradigm placed some of our children in an uncomfortable position; do they choose to attend a group based on their sex assigned at birth or based on their gender identity? Further, the activities in each of these clubs were stereotypically feminine and masculine; the girls made crafts while the boys played team sports. Our actions spoke to the masculine and feminine gender norms at play in our school community. The day we came to this realization, we experienced intense discomfort. We pride ourselves on valuing every child and in this instance our actions did not reflect our beliefs. In response, we changed the name of the club to the "You Be You" club and all children were invited to attend. Staff and students worked together to explore personal uniqueness, strengths, interests, and challenges. This small change in language and purpose has helped us genuinely honour the diversity amongst our school community members and has prompted us to critically examine other routines and traditions. 
My intense emotional reaction to Haertling Thein's article was due in part to my recently becoming aware of our district's Sexual Orientation and Gender Identity (SOGI) policy. ${ }^{5}$ When our research group engaged with this article, I was immediately struck by how our policy nullifies the arguments brought forward. No matter one's personal perspective, or what excuses one has, creating a safe and caring environment for our LGBT children is not only a human rights issue, but also our professional responsibility. Our policy provides a supportive foundation for the work we do within our school-a safety net when confronted by staff, parents, or students about why we actively engage with LGBT issues. Part of the policy ensures each school has at least one staff member trained as a Safe Contact. The role of a Safe Contact is to engage and support gender minority and questioning students and their families so they feel safe, included, and respected while encouraging them to actively participate in and contribute to their schools and communities.

I attended Safe Contact training and participated in a powerful activity entitled, Coming Out Stars Activity. Through this activity, participants were invited to explore privilege and heterosexism and to reflect on their own behaviours and beliefs around sexuality. The instructor gave each participant a star, representing our worlds, and asked us to write the names of personally significant people in response to a variety of prompts. Once each point on the star contained a name, participants gathered in a large circle and the instructor gave instructions, such as: if your star is orange, your family member rejects you when you come out as LGBT and you are thrown out of your home and disowned. Participants were asked to tear off that point and let it fall to the floor.

As the activity continued, the empathy, compassion, and sadness in the room were palpable. Participants reflected emotionally on the toll our reactions and choice of words can take on others. This experience left me with intense feelings of both sadness and hope. My sadness came from a place of regret for those who have been silenced by others due to their difference. As Boler and Zembylas (2003) explain, "(d)ifference is produced not only through an explicit naming but also through the power of silence and absence" (p. 120). My sense of hope came from knowing I am part of a district that truly honours and works purposefully to include and celebrate all members of our school community. 


\section{Discussion and Pedagogical Implications}

As we reflect on Theresa's professional development efforts, we ask ourselves what enabled Theresa to push the boundaries of possibility. We feel the answer, at least in part, relates to her comfort level with discomfort. And, although we wish it were not so, we acknowledge that Theresa is likely the exception in this regard. In this section, we explore what this means for educational practice and professional development.

By and large, the literature in the field confirms Haertling Thein's findings of teacher resistance to LGBT issues and literature. For example, Puchner and Klein's (2011) study of middle-school language arts teachers found that while all teacher participants "recognized that the topic of same-sex sexuality was important for their students,... the teachers used a variety of strategies to avoid or redirect discussion of the topic" (p. 233). Other studies report similar results (see for example, Clark, 2010; HermannWilmarth, 2010, Larrabbee \& Morehead, 2010; Schneider \& Dimito, 2008). Shifting societal expectations around LGBT issues creates challenges for teachers who are uncomfortable with this aspect of difference. Boler and Zembylas (2003) explain that views of difference reflect various emotional stances, for example, tolerance or denial. They argue that what is common to these "emotional stances is an unwillingness to engage the difficult work of (re)constructing one's own beliefs, values, and assumptions. There is understandable reluctance to encounter one's fears, and instead one may cling to particular safety zones" (p. 114). While we sympathize with the desire to stay within one's comfort zone, we do not accept teacher discomfort as a satisfactory justification for avoiding difficult issues in the classroom. How can teachers be encouraged to adopt a pedagogy of discomfort for the sake of their students? The implications of this question for practice take us back to Theresa's remark that what teachers, who are supportive but nonetheless resistant, need is a combination of awareness and support. This mixture can be seen in the following claim, made by Theresa during the inquiry group discussion:

Well personally I would read any of the books and I think I feel strong enough about why it's important that I can articulate that clearly enough for anybody who wanted to challenge it. So, I would feel comfortable doing it...I think others will protest would be a big one, but I know our principal's very supportive. She wants to order lots of the children's books on the challenged books list. SOGI issues, or LGBT, is very underrepresented in our library for sure.

The "under-representation and use of LGBTQ resources in classrooms and libraries" (p. 207) is highlighted in McNeil's (2010) chapter, Everybody But Me: Social Justice and 
Literacy Learning. According to McNeil, the "inadequate response of school libraries to the resource/information needs of LGBT and queer students" (p. 189) is a Canadian social justice issue. This is but one of many ways that having a supportive administration is no small consideration when it comes to LGBT issues and literature.

While Theresa would have pushed the boundaries regardless of the type of support she received, she allows that her initiatives would not have been as successful without support, at both school and district levels. In terms of pushing boundaries, the support of the inquiry group, while helpful, was not crucial for Theresa. However, not all teachers are as fortunately positioned. A case in point is Kevin, one of the participants in our study; Kevin provides a striking contrast to Theresa, in both his awareness of and comfort with LGBT issues and literature. Unfortunately, Kevin missed the meeting when we were discussing the article. In the next meeting, the topic resurfaced as Theresa gave a SOGI update. Kevin admitted to the group that he did not know how to navigate the topic:

I had twins in my class last year, and they had two moms. I had no idea how to do this. I felt really kind of lost...Luckily, they were both reasonably good students, and pretty good kids too. But, the thing is, it was more my problem...because I was uneasy. I'm not against it, just I was uneasy.

As with the teachers in Haertling Thein's study, Kevin could be described as antihomophobic, but likewise resistant. Using Haertling Thein's categories, the justification that best describes Kevin is ability/preparedness ("I would but I don't know how"). Kevin's feelings of not knowing how were likely aggravated by the reality that he taught at a traditional charter school. ${ }^{6}$ The charter school where Kevin taught was known for its academically oriented program, highly structured environment, and teacher-directed instruction. Kevin explained that LGBT issues were not discussed by his colleagues, nor was his school in the district with the SOGI Policy. Unlike Theresa, Kevin felt he had backing at neither level. Given this, the support of the inquiry group was particularly crucial if Kevin were to push boundaries, as can be seen by his explanation:

Well that's the thing (not being covered by SOGI). At my charter school, we're basically in a box and I've been in that particular box for a long time, and just to come here and to listen to you guys talking about this was informative, at times even humbling because these are things that I hadn't even thought of approaching.

The inquiry group conversation increased Kevin's awareness of the topic and of the available literature and resources. And, as the research project budget allowed for 
purchase of resources, if Kevin had decided to teach one or more LGBT texts, the group would offer moral support as well as teaching suggestions. Such a choice could be of benefit, as can be seen by the following remark: "I would find myself saying things like, 'Well, go and ask your mom about this.' I wasn't going to say, 'Go and ask your moms.' But, you know I was just awkward and I just didn't know the language."

Once again, our discussions could assist Kevin with his heteronormative language; and, had he known about the book, Asha's Mums, he could have read it to his class as a first step. Fittingly, one of the challenges the main character in Asha's Mums faces is to get her teacher to accept that she has two mums. Wouldn't "Go and ask your moms" be more appropriate in Kevin's situation (akin to "Go and ask your parents")?

In our comparison of Kevin and Theresa's differing circumstances, we return to the contrasting stances found in anti-work and ally-work. We value Clark's (2010) critique of anti-work as neutral and apolitical, and agree with Clark and Haertling that antiwork is not enough. What Theresa has undertaken in her school provides a powerful exemplar of professional development in the form of ally-work. However, as educators, we certainly acknowledge the importance of an anti-stance towards LGBT issues. Teachers, like Kevin, who lack awareness and support, may not be ready for ally-work; in such cases, anti-work (confronting, rather than ignoring, students who use derogatory language, for example) is an important place to begin.

As Boler and Zembylas (2003) explain, the vulnerability that accompanies a pedagogy of discomfort "must apply as much to the educator as to the students" (p. 130). As a result of Theresa's professional development initiatives, both educators and students at her school were "able to gain a new sense of interconnection with others and expand the borders of comfort zones" (p. 133). Our hope is that the professional development provided by the inquiry group will result in Kevin and his future students experiencing growth of this nature as well.

\section{Conclusion}

In conclusion, we return to Erica, the pre-service teacher whose plans to use a samesex themed text were halted by an unsupportive school administrator. In the following interview excerpt, Erica describes the remainder of her conversation with the principal, and its effect on her thoughts about her future career as a teacher: 
As he requested, I did not use the book and that was the end of the issue-there it was, swept under the rug. I was upset about it. I felt that he was really closed minded, suggesting that this kind of school isn't ready for a book like this... And, I was frustrated by the power differential of being just a student teacher. It made me think about what the future might hold for me. What if I encounter this situation again, only this time I am a paid person on someone's staff? Am I willing to go to bat for this cause? Am I willing to be the teacher that takes this the distance?

Given what may be at stake, especially for beginning teachers, these are questions with no easy answers. If the participants in Haertling Thein's study are any indication, there may be a shortage of teachers prepared to take on this cause, and no wonder, if Erica's experience is common. However, we like to think that Theresa's story is more representative of the changing times regarding LGBT issues. Our hope is that it is now less easy to sweep LGBT issues under the rug. Earlier, Lynne drew a parallel between the Canadian and American settings of the research studies; however, we would like to note a difference as well. Canada, in general, is a more accepting society towards the LGBT community, particularly in education. For example, in our inquiry group discussion following the reading of the article, the only argument not directly addressed was force of facts; we believe this is because in Canada, teaching about LGBT issues is not explicitly prohibited, or considered illegal, as it was in some of the contexts noted in Haertling Thein's study.

Still, there is much work to be done, if LGBT children or those with LGBT family members are to see themselves in the literature or hear conversations about their lives in classroom. For educators willing to go to bat for the cause, Smolkin and Young (2011) offer educators suggestions for achieving inclusivity:

...you can begin by updating your resources... Beyond bringing new resources into your classrooms, you can bring a critical eye to professional books and journals, noting how diversity is defined and presented. You can determine which voices are affirmed and which are marginalized or silenced...If you are uncomfortable incorporating discussions of LGBT topics in your classroom, find someone in the community who can. (p. 224)

We are paying close attention to these suggestions. Theresa's school has updated its library with LGBT resources. Lynne has introduced her students and research participants to professional literature that examines LGBT issues. We have brainstormed with teachers at Language Arts and Gay Straight Alliance conferences about ways to work with teacher discomfort so that voices too long silenced are heard. By providing 
an example of professional development that encourages teachers to resist resistance of LGBT literature and issues, we hope we have encouraged other educators and educational researchers to push the boundaries of possibility-'cause it has to happen.

\section{Notes}

1. As our paper is a response to Haertling Klein's article, for the most part, we use the term LGBT, in keeping with the author. However, we acknowledge that terminology varies; accordingly, at other times we use what is most contextually appropriate (e.g., LGBTQ).

2. Pseudonyms have been used for all research participants mentioned with the exception of Theresa.

3. For more information on this national study, Preservice Teachers' Perspectives on Canadian Identity and Their Understandings of Ideology in Multicultural Picture Books, please see Johnston \& Bainbridge (2013).

4. Due to space constraints, we cannot elaborate. For more detail on the court case, see Oberg (2003).

5. Resources can be found on the SOGI website: https://sites.google.com/a/share.epsb. $\mathrm{ca} /$ sogi-resources/

6. Charter schools have characteristics that set them apart from other public schools in meeting the needs of a particular group of students through a specific program or teaching/learning approach while following Alberta Education's Program of Studies. (Alberta Education, 2015)

\section{Acknowledgments}

We are grateful to SSHRC (Social Sciences and Humanities Research Council) for the financial support that made this study possible. 


\section{References}

Alberta Education. (2015). Charter schools. Retrieved from https://education.alberta.ca/ parents/choice/charter.aspx

Bender-Slack, D. (2010). Texts, talk ... and fear? English Language Arts teachers negotiate social justice teaching. English Education, 42(2), 181-203.

Boler, M., \& Zembylas, M. (2003). Discomforting truths: The emotional terrain of understanding difference. In Trifonas, P. P. (Ed). Pedagogies of difference: Rethinking education for social change (pp. 110-136). New York: RoutledgeFalmer.

Bonilla-Silva, E., \& Forman, T. (2000). "I'm not a racist, but...": Mapping white college students' racial ideology in the USA. Discourse \& Society, 11, 50-85. doi:10.1177/0957926500011001003

Carr, W., \& Kemmis, S. (1986). Becoming critical: Education, knowledge and action research. London: Falmer Press.

Cherland, M., \& Harper, H. (2007). Advocacy research in literacy education: Seeking higher ground. London: Lawrence Erlbaum Associates.

Clark, C. (2010). Preparing LGBTQ-allies and combating homophobia in a U.S. teacher education program. Teaching and Teacher Education, 26, 704-713. doi:10.1016/j.tate. 2009.10.006

Cochran-Smith, M. (2004). Walking the road: Race, diversity, and social justice in teacher education. New York: Teachers College Press.

Cochran-Smith, M., \& Lytle, S. L. (2009). Inquiry as stance: Practitioner research in the next generation. New York: Teachers College Press.

Elwin, R., \& Paulse, M. (1990). Asha's mums. (D. Lee, Illustr). Toronto: Women's Press.

Haertling Thein, A. (2013). Teachers' resistance to LGBT literature and issues. Language Arts, 90(3), 169-180.

Hermann-Wilmarth, J. (2010). More than book talks: Preservice teacher dialogue after reading gay and lesbian children's literature. Language Arts, 87(3), 188-198.
Johnston, I., \& Bainbridge, J. (Eds.) (2013). Reading diversity through Canadian Picture books: Preservice Teachers explore issues of identity, ideology and pedagogy. Toronto: University of Toronto Press.

Larrabbee, T., \& Morehead, P. (2010). Broadening views of social justice and teacher leadership: Addressing LGB issues in teacher education. Issues in Teacher Education, 19(2), 37-52.

Larrick, N. (1965, September 11). The all white world of children's books. Saturday Review, 63-65, 84-85.

McDonald, M. (2007). The joint enterprise of social justice teacher education. Teachers College Record, 109(8), 2047-2081.

McNeil, B. (2010). Everybody but me: Social justice and literacy learning. In M.C. Courtland \& T. Gambell (Eds.), Literature, media \& multiliteracies in adolescent language arts (pp. 189-211). Vancouver: Pacific Educational Press.

Oberg, D. (2003). School board wrong to ban same-sex books-Implications of Supreme Court Decision on Chamberlain v Surrey School District No. 36. ATA News, 37(10).

Puchner, L., \& Klein, N. (2011). The right time and place? Middle school language arts teachers talk about not talking about sexual orientation. Equity \& Excellence in Education, 44, 233-249. doi:10.1080/10665684.2011.563182

Schneider, M., \& Dimito, A. (2008). Educators' beliefs about raising lesbian, gay, bisexual, and transgender issues in the Schools: The experience in Ontario, Canada. Journal of LGBT Youth, 5(4), 49-71.

Setterington, K. (2004). Mom and Mum are getting married. (A. Priestley, Illustr.). Toronto: Second Story Press.

Shields, C. M. (2004). Dialogic leadership for social justice: Overcoming pathologies of silence. Educational Administration, 40(1), 109-132. 
Smolkin, L., \& Young, C. (2011). Missing mirrors, missing windows: Children's literature textbooks and LGBT topics. Language Arts, 88(3), 217-225.

Wenger, E. (1998). Communities of practice: Learning, meaning and identity. Cambridge: Cambridge University Press.
Wiltse, L. (2015). Mirrors and windows: Teaching and research reflections on Canadian Aboriginal children's literature. Language \& Literacy, 17(2), 22-40.

Wolk, S. (2009). Reading for a better world: Teaching for social responsibility with young adult literature, Journal of Adolescent \& Adult Literacy, 52(8), 664-673.

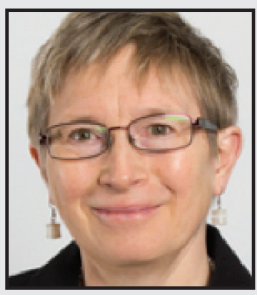

Lynne Wiltse is an Associate Professor in the Department of Elementary Education at the University of Alberta where she teaches courses in the areas of language and literacy and children's literature. She holds a PhD from the University of Alberta. Previously, she taught in First Nations communities in British Columbia. Her research interests include multicultural children's literature, teaching for social justice, minority language education, sociocultural theory, teacher education, and qualitative methodologies. Dr. Wiltse has published on the topics of pedagogy for English language learners, Aboriginal English, Canadian children's literature, and text selection and cultural diversity.

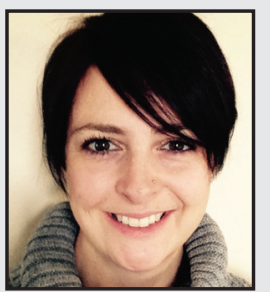

Theresa Boyko is an Assistant Principal at an elementary school in Edmonton, Alberta. She holds a Master's degree in Educational Studies: Leadership and School Improvement from the University of Alberta and is currently a doctoral student in Educational Administration and Leadership. Her research interests include school culture and social-emotional competencies. Theresa is passionate about creating a teaching and learning environment where purposeful attention is paid to developing a sense of belonging and personal empowerment. Her background includes facilitating school-based cultural change and refocusing learning to include the development of social-emotional competencies. 